\title{
VIEWPOINTS
}

\section{Conversion Issues in Malaysia: A Challenge to Religious and Racial Harmony}

\author{
Sheila Ainon Yussof ${ }^{*}$
}

There is a worrying trend recently of inter-religious cases which have fuelled angst amongst multiracial communities in Malaysia, and which threaten to disrupt racial harmony or dismantle the 1MALAYSIA Unity Framework. We refer to the recent case of a "Muslim" bride (named Zarina Majid) marrying her Hindu boyfriend of seven years.

The earlier version of her story goes like this. Zarina was a product of the law which at its time allowed a unilateral conversion of minors by their parents who converted to Islam. Zarina's parents married as Hindus in 1980. Her father converted to Islam at the urging of a relative while her mother remained a Hindu. It was reported that they remained in the "dual-religion" marriage for a good number of years, and Zarina said that her mother, being illiterate, did not realise that her children were Muslims. Her father registered them as Muslims in their birth certificates and in their MyKad (the national identity card). The problem arose when their father left his home after the birth of Zarina's brother in 1990 and abandoned them. As a result of abandonment, Zarina was Muslim in name only, nurtured by her Hindu mother to become a practising Hindu, whilst the Muslim father moved on with his life presumably to marry a Muslim wife.

Zarina's version was refuted by her father. He revealed that both he and his wife converted to Islam and registered their children as Muslims-it was not a case of unilateral conversion of a minor. He did not abandon them but was kicked out of the house at the behest of his wife, who insisted on going to the temple to practise the Hindu faith. As a result of the wife's upbringing, the children eventually became Hindus.

Whatever the circumstances or the veracity of the statements made by Zarina or her father, the law in Malaysia as it stands today completely prohibits a marriage between a Muslim and non-Muslim as it would violate the prevailing Islamic norms upheld in Malaysia. Herein lay the offence, blown out of proportion, when Zarina as a Muslim was marrying a Hindu according to Hindu rites. It was the irresponsible behaviour of the mother or the father that the Shari'ah court, the National Registration Department and JAIS (Jabatan Agama Islam Selangor, or Selangor State Islamic Religious Department) had to take the pot- 
shots. JAIS was attempting to protect Islam but its "overzealousness" diluted its well intentioned effort.

We sympathise with Zarina as she has made countless trips for the last seven years to the Shari'ah Court and the National Registration Department (NRD) hoping to remove the word "Islam" from her identity card, since she is not a practising Muslim. The Federal Court ruling clearly stated that "a Muslim who wanted to renounce Islam must get the certificate from the religious court before other documentation could be completed." Granted there were bureaucratic delays, yet there is no discrimination here against racial minorities. Muslim women practising their faith also face the same bureaucratic inefficiencies with the Shari'ah court, and we understand the concern of Zarina to get on with her life. It may be the fault of the system or the staff, but Islam should not be held responsible.

What the Hindu temple officials failed to do was to ensure that a 'Certificate of Renunciation' was issued before proceeding with the wedding ceremony. Failing to do so made them an accomplice to the offence. In this case, JAIS was merely doing its job to prevent an offence before it is committed. A marriage of a Muslim with a non-Muslim is not allowed in Malaysia, unless the non-Muslim spouse converts to Islam. It is a statutory offence and there is no need for JAIS to listen to the plight of the bride and her futile attempts to change her religious status. Also there is no need for JAIS to be overzealous, if that was what it was accused of. If we were to take the law into our own hands we would be faced with the same embarrassing situation in the form of khalwat. South of Malaysia in a Muslim-minority country, I was told by a scholar that the system in Singapore takes a stricter approach: the moment a Muslim is involved in a religious offence, no matter whether he was practicing his religion or not, the matter will be immediately referred to MUIS (the Singapore Islamic Religious Council) who will decide the course of action to follow, with the full force of the law behind it. The scholar was relating the story of "body snatchers", where a deceased (a registered but not a practising Muslim) was about to be cremated by his Hindu relatives, when MUIS was alerted and a compromise was made to defuse the situation: they allowed the Hindu rites to be performed first symbolically; and then MUIS took over his funeral and burial rites as a Muslim.

In the frenzy of debate over the constitutional rights of Zarina, her father and mother (both Malaysian citizens and revert Muslims-whether practising or not) get away blameless. Are the parents not ultimately responsible for failing to look after the status of their children, which then led others to ridicule or blame Islam itself for causing these problems - and which escalated into Islambashing? Zarina has three other siblings who will be trapped in the same situation unless it is remedied. Conversion to Islam means voluntarily accepting the faith without fear or favour and with no compulsion. Islam does not encourage 
conversion for convenience, nor does it invite opportunist converts merely to balloon the number of adherents. Conversion to Islam does not mean it should be used as a convenient tool to betray trust or abandon family commitments or enjoy any material benefits. Islam neither condones irresponsible behaviour and uncaring and unethical conduct, nor allows the use of such conversion issues to gain political mileage. There is a need to revisit the conversion issue from every angle of law and cultural sensitivities and thereby resolve this problem through objective ways - rather than go witch-hunting.

In this scenario, we must be aware that the press never ceases to sensationalise news that might tarnish the image of Islam. Sensational headlines have appeared which easily incite racial and religious sentiments and foster distrust amongst different religious communities. Similarly, when a terrorist attack occurs elsewhere, the media reports it as "Muslim terrorists", while the labels Hindu, Buddhist, Jewish or Christian terrorists never appear in the tabloids. There is a need for responsible and unbiased reporting - especially in a multiracial society. "Islamophobia" has been imported into Malaysia, and thus, interfaith dialogue is needed among different sectors of society, including the press, social activists and think-tanks in order to ensure mutual respect and to defuse language that may stir or insult any race or religion. Even more importantly: vote seeking politicians must also refrain from spouting statements which aggravate the delicate balance between religions.

This embarrassing situation could have been avoided by using common sense and engaging competent people with compassion and fairness to ensure that the law is respected and complied with, for no one is above the law. The tip-off must be investigated, and the temple officials should be alerted to the seriousness of the offence that they committed when they conducted the marriage ceremony. If they ignored such a warning, they should face the consequences. If the tipoff came whilst the ceremony was being performed, the ceremony should be allowed to proceed as the wedding will not be lawful in the eyes of the law in any case, and it becomes cogent evidence of violating the law. However, the fact that the bride was deliberately flouting the law (she was reportedly fed up with bureaucratic delays and anxious to start a family) will not excuse her from legal culpability. If this is the case, then she may have committed a legal offence-by going through the wedding ceremony according to Hindu rites, in order to bring disrepute upon Islam - under the Shari'ah Criminal Enactment (Selangor) 1995. Hers was not a genuine case of "apostasy" as she was not a practising Muslim at the time of her marriage.

Although JAIS is empowered under state enactments to make arrests without warrants based on "reasonable suspicion", this does not allow it to exceed "the boundaries of what is decent". Even if it was within its purview to investigate 
offences against Islamic law, the department must explain its rationale for disrupting a non-Muslim wedding. There is also no need for the community to fan the flames of racial discontent and to inject racial overtones into this offence. The racial sensitivities of multicultural Malaysia need to be respected, and people of the same race (Indian Muslims in Zarina's case) should be allowed to handle the matter in a more tactful and cross-cultural way. Certainly JAIS could have handled this issue more tactfully. Heavy handed and rash responses encourage more "Islam-bashing", insinuations of "Malay supremacy" and the dangerous creation of divisive tensions between races and religions. These unhealthy manifestations can be exploited by subversive elements who seek to sow the seeds of disunity in Malaysia.

The zealousness of religious authorities responsible for conversion, marriage and divorce, to catch offenders should be matched by an enthusiasm to get to the root of the problem by weeding out inefficiencies - the infamous bureaucratic delays, the familiar run-arounds, the "watch-the-show-first and then nab offenders in order to humiliate" (which is clearly un-Islamic), for justice delayed is justice denied.

Taken as a whole, Zarina's case demonstrates the importance of obtaining both parents' consent to determine the religion of their children and proper upbringing in that particular faith which would impact their welfare and future life. This is especially so whenever a divorce occurs due to only one parent converting to Islam. In recognising the problems involved in the conversion of minors, the Malaysian Cabinet in 2009 questioned the presumed right of the converting father to unilaterally convert his children (as minors) to his chosen religion. It also declared that if both parents cannot come to an agreement on the religion of their children, then the children should be allowed to maintain the original faith of the parents at the time of the latter's civil marriage.

To conclude, if both parents were involved right from the beginning in determining their children's future religious identity and the religious upbringing they should receive, then a distressing situation like this could not surface.

\section{Notes}

* Sheila Ainon Yussof, Senior Analyst with IAIS Malaysia who heads the Policy Issue Paper Editorial Committee and is specialising in policy-relevant research in Islamic Finance, Waqf development, women and family development, gender empowerment. Formerly an advocate and solicitor for thir-teen years in her own legal practice. (Email: sayussof@iais.org.my) 